\title{
ERアクチュエータを用いた リハビリテーション訓練システムの開発に関する基礎研究
}

\author{
坂 口正道*1 古 荘 純 次*1 元田 英 一*2
}

\author{
Basic Study on Development of Rehabilitation Training System \\ Using ER Actuators
}

\author{
Masamichi Sakaguchi*1, Junji Furusho*1 and Eiichi Genda*2
}

\begin{abstract}
Robot and virtual reality technologies may be applied to rehabilitation training so that fewer human therapists are needed, training can be quantitatively evaluated, and training can be more enjoyable to patients. A training system in rehabilitation can use robot or other virtual reality technologies, but it must be far safer than ordinary industrial robot systems. The authors have been studying actuators, which are safe and easy to control, and have developed force display systems using such actuators. As an application of force display technology, they have developed a rehabilitation training system using ER actuators. The authors have also developed a computer program for the system, which evaluates the physical capability of the upper limbs of patients and assists in their rehabilitation training. This paper is a summary of the basic experiments with the system as applied at a hospital to patients suffering from upper limb paralysis.
\end{abstract}

Key Words: Rehabilitation Training System, Actuator, ER Fluid, Force Display, Virtual Reality, Robotics

\section{1.はじめに}

社会の高齢化が進み，リハビリテーションを必要とする人の 数が増加するとともに，若年労働力の不足も懸念されている. リハビリテーションの分野においても介護者不足等が予想され， この分野へのロボット技術の導入が期待されている [1]〜 [3]. 近 年研究も盛んになり, 上肢訓練装置 $[4] \sim[6]$, 下肢可動域訓練口 ボット [7], 歩行訓練機 [8], トレッドミルやエルゴメータ [9] な ど, 様々な種類の機器が開発されている.

リハビリテーションに用いられるロボットは，常に人と直接 接触しながら作業を行うため産業用ロボットとは異なった特性 が要求される [10]. ロボットのアクチュエータとしては電動サー ボモータが最も多く用いられているが，特に減速機と組み合わ せて用いられるモータは, バックドライバビリティ, 制御特性等 を考えると，必ずしもリハビリテーション訓練システムに用い るアクチュエータに適しているとは言えない.これに対し, 空 気圧アクチュエータ [5], 水素吸蔵合金アクチュエータ [11], あ るいは静電アクチュエータ [12] 等の利用について検討が行われ ている.

\footnotetext{
原稿受付 2000 年 2 月 23 日

*1 大阪大学大学院工学研究科

*2労災リハビリテーション工学センター

${ }^{* 1}$ Graduate School of Engineering, Osaka University

${ }^{* 2}$ Rosai Rehabilitation Engineering Center
}

筆者らは，これまで ER 流体を用いたアクチュエータ（ER アクチュエータ) の開発および制御に関する研究を行ってき た [13] [14]. ER 流体とは，電場を印加すると見かけ上の粘性が 変化する機能性流体の一種である.アクチュエー夕の力発生部 に ER 流体を用いることで, 応答性, 安全性に優れるなど, 従来 のサーボモータと比べて人に優しい特性を持つアクチュエータ が開発できる。この特徵を活かし，筆者らは ERアクチュエー 夕を用いた力覚提示システムの開発を行っている [15]. 本研究 では, ERアクチュエータのリハビリテーション訓練システム への応用に関する基礎的検討を行った。

本論文の構成は次の通りである. 2 章では, ER 流体の紹介, $\mathrm{ER}$ クラッチの原理, ER アクチュエータの概要および特徴につ いて述べる， 3 章では，ERアクチュエータをリハビリテーショ ン訓練システムに導入することの利点についてまとめ, 開発し たリハビリテーション訓練システムについて述べる. 4 章では, リハビリテーション訓練の中でも, 上肢の巧緻性, 協調性の評 価・訓練を想定した実験プログラムを開発する。また, 研究室 および病院内で実施した基礎実験の結果を示し, その効果につ いて考察する.

\section{ERアクチュエータ}

\section{$2.1 \mathrm{ER}$ 流体の特性}

ER 流体（電気粘性流体, Electrorheological Fluid) [16] [19] とは近年注目を集めている機能性材料の一つで, 電場を印 
加することで見かけ上の粘性（レオロジー特性）が変化する. ER 流体として様々な流体 [17] が開発されているが, 本研究で は, 旭化成工業（株）から提供を受けた非含水系の粒子系 $\mathrm{ER}$ 流体を用いている。

粒子系 ER 流体は Fig. 1 に示す特徵を持つ。この図は, 電 極間に ER 流体を充填した際の電極の相対せん断速度と発生す るせん断応力の関係を示したモデル図である. ER 流体は, 電 場を印加していない $(E=0)$ 時は, 図中の破線に示すように ニュートン流体の特性を示す。これに対し, 電極間に電圧を印 加する $(E \neq 0)$ と流体の粘性が大きく変化し, 図中の実線に 示すようにビンガム流体としての特性を示す。この時発生せん 断応力はせん断速度にほとんど依存せず，ほぼ印加電場にのみ 依存する。つまり, 電極間にクーロン摩擦でモデル化できる力 が発生し, その力が印加電場によって制御できる. そこで, こ の粒子系 $\mathrm{ER}$ 流体をクラッチ（アクチュエータ）に応用した。 本研究で用いた ER 流体は, DC3 $[\mathrm{kV} / \mathrm{mm}]$ の電場印加時に約 $1.2[\mathrm{kPa}]$ のせん断応力を発生する.

\subsection{ER クラッチの原理と特徵}

Fig. 2 に，ER 流体を用いたクラッチの原理図を示す. 入力 円筒は，他のアクチュエータにより一定速度で駆動される. 入 力円筒と出力円筒の隙間に ER 流体が充填される. 入力円筒と 出力円筒はともに電極となり, 電場を印加すると電極間の $\mathrm{ER}$ 流体の粘性が増加し, 出力軸にトルクが伝達される。この $\mathrm{ER}$ クラッチに入力円筒駆動部を含めたシステムを, 筆者らは ER アクチュエータと呼んでいる.

$\mathrm{ER}$ アクチュエータは次のような特徴を持つ.

（1）力発生部に ER 流体を用いているため, ER アクチュエー 夕の出力特性は流体以降の出力部のみの特性となる.つま

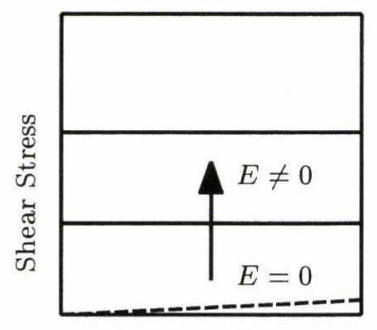

Shear Rate

Fig. 1 Characteristics of particle-type ER fluid

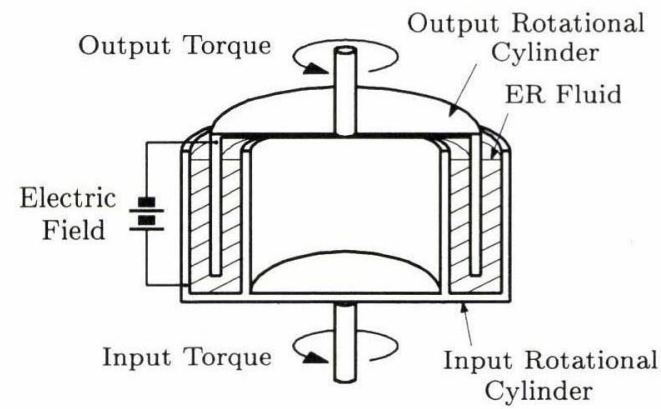

Fig. 2 Principle of ER clutch
り, ER 流体以前の入力円筒の慣性モーメントや入力円筒 の速度変動等の影響は出力にほとんど影響せず，制御性に 優れる $[13]$.

(2) 出力部は構造が非常にシンプルなので, 軽量で強度の強い材 料を用いることで, 出力部の慣性モーメントを小さくしやす い. また, 電極表面に発生する力を利用しているため, 多重 円筒構造等を用いることで, 電磁原理を用いたアクチュエー 夕に比べてトルク/慣性比の大きなアクチュエータを開発 できる。この傾向は小型化することでより顕著になる $[20]$.

(3) ER 流体の電場の変化に対するせん断応力の応答速度は非 常に高速である。したがって，ERアクチュエータの発生 トルクの時定数も $3 \sim 5[\mathrm{~ms}]$ と高速である [13].

\subsection{ER アクチュエータの開発}

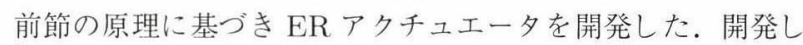
たERアクチュエータの断面図を Fig. 3 に，その写真を Fig. 4 に示す. Fig. 2 に示す原理と同じ構造の ERアクチュエータは, 入力円筒が常に一方向に回転している場合, 得られる出力トル クも一向のみとなる。ここで, 入力円筒の回転方向を逆転さ せれば逆方向の出力トルクが得られるが,この場合, 入力円筒 を駆動するシステムの応答が ER アクチュエータの応答となっ てしまい, 高速な応答が困難となる。そこで, 開発した ER ア クチュエータには, 一つの出力円筒部に対し二つの入力円筒部 を用いている。二つの入力円筒部は，一つのモー夕を用いてギ アを介することによりそれぞれ正転, 逆転方向に一定速度で駆

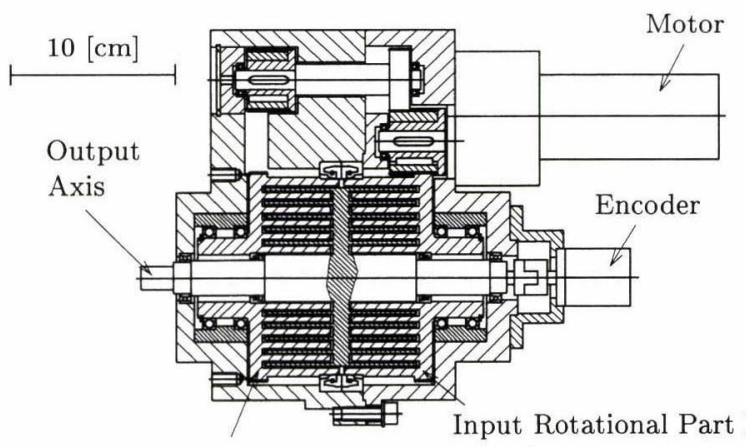

Input Rotational Part II

(Negative Rotation)

(Positive Rotation)

Fig. 3 Sectional view of ER actuator

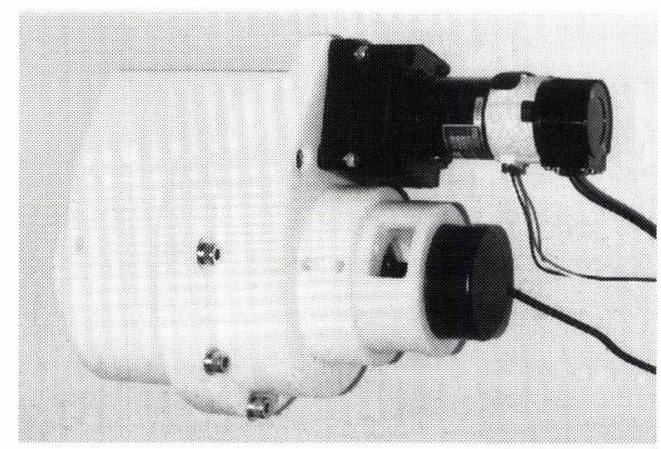

Fig. 4 Developed ER actuator 
動される：二つの入力円筒部，および出力円筒部は電極となる. 出力円筒部がグランドで，二つの入力円筒部に印加する電圧を 制御することで両方向の出力トルクを得る. 大きな出力トルク を得るために，電極部は多重円筒構造となっている.

ER アクチュエータの各係数は, 出力円筒最大外径 $110[\mathrm{~mm}]$, 電極間距離 $1.0[\mathrm{~mm}]$, 慣性モーメント $1.40 \times 10^{-3}\left[\mathrm{~kg} \cdot \mathrm{m}^{2}\right]$, 片 側の有効電極面積 $955\left[\mathrm{~cm}^{2}\right]$ である. ER アクチュエータの最大 出力トルクは用いる ER 流体の性能によって変化する. 本研究 の実験では, $3[\mathrm{kV} / \mathrm{mm}]$ の電場を印加したとき $1.2[\mathrm{kPa}]$ のせ ん断応力を発生する ER 流体を使用した。その結果, $3[\mathrm{kV}]$ の 電圧を印加したときの発生トルクは $4.8[\mathrm{Nm}]$ となる。 さらに, 同じ印加電場に対し発生せん断応力の大きな ER 流体を用いる ことで, 出力トルクは増加し, トルク/慣性比も大きくなる. 現 在，5[kPa] を超えるせん断応力を発生することができる ER 流 体が開発されている，出力軸にはロータリーエンコーダが取り 付けられており, アクチュエータの回転角度を計測する. エン コーダの分解能は $1,296,000[\mathrm{P} / \mathrm{R}]$ である．ER アクチュエー 夕については，力制御 [13]，速度制御および位置制御 [14] に関 する娭討が行われている.

\section{ER アクチュエータを用いたリハビリテーション訓練 システムの開発}

\section{$3.1 \mathrm{ER}$ アクチュエータを用いる利点}

リハビリテーション訓練システムへの ER アクチュエータの 応用について検討する。アクチュエータを用いたシステムは一 種のロボットと考えられる。しかし，リハビリテーション訓練を 行うためには常に人間と接触しながら作業を行わなけ机ばなら ないため, 制御特性のみでなく安全性やバックドライバビリティ など一般の産業用ロボットとは異なる特性が要求される。機器 の特性には用いるアクチュエータの特性が大きく影響する。リ ハビリテーション訓練システムに ER アクチュエータを用いる ことで, 次のような利点が期待される.

（1）リハビリテーション訓練では，訓練動作の教示を行ったり， 訓練者に無理な力をかけないためにも，バックドライバビ リティが重要となる。産業用ロボット等に多く用いられて いる減速機付のサーボモー夕を用いた場合, 減速機の摩擦 やモー夕側の慣性モーメントの影響のため，そのままでは バックドライバビリティがよくない．また力センサ等を用 いて力制御を行った場合，構造および制御系が複雑化して しまう。これに対し，ERアクチュエー夕は比較的大きな トルクが得られるため減速比の大きな減速機を用いる必要 がなく，また慣性モーメントも小さいためバックドライバ ビリティに優れる。

（2）リハビリテーション訓練では，ストレッチ運動など比較的 大きな力を必要とする訓練がある，大きな出力の得られる ダイレクトドライブモータ（DDモータ）や空気圧アクチュ エータなどを用いた場合，非常に大きな加速度を生じる危 険性があるため, 複雑に何重もの安全対策を講じる必要が ある。これに対し，ERアクチュエータは一種のクラッチ なので, アクチュエータの出力として発生できる最大回転 速度は，入力回転部の回転速度を越えることはない，従っ
て，目的にあわせて入力回転部の速度を適切に設定するこ とで，大きな力を出力している場合でも，必要以上に加速 する危険な状態を機構的に防ぐことができる.

（3）リハビリテーション訓練では，従来セラピストが徒手によっ て行っていた微妙な力加減を制御により実現しなければな らない，例えば，七ラピストの手先のインピーダンスが高 い状態を高ゲインフィードバック制御を用いて表現する場 合, アクチュエータの遅れが大きいと制御が不安定になっ てしまうため, アクチュエータの応答性が重要となる。従 来トルク/慣性比の大きな要素としてパウダクラッチが用 いられているが, パウダクラッチは内部の磁性粉体の応答 が遅いため, 発生トルクの時定数は数十一数百ミリ秒程度 である。これに対し，ER 流体の発生トルクの時定数は数 ミリ秒と高速であり，ER アクチュエー夕は制御特性に優 れる. ER アクチュエー夕を用いることで優れた力覚提示 システム $[15]$ が開発でき, 微妙な訓練動作を実現すること が可能となる.

（4）万が一訓練者がダメージを受けそうになった場合は即座に 訓練を中止しなければならない。このとき, 出力の遮断に 電磁クラッチなどの機械的な可動部を持つクラッチを用い た場合, 出力が完全に遮断されるまでに遅れが生じる。例 えば，ロボットから人間に過大な外力がかかったときに力七 ンサ等の情報を用いて出力を遮断する場合, 電磁クラッチ が動作するわずかな遅れの間でも大きな力が人間にかかっ てしまい危険な場合がある。これに対し，ERアクチュエー 夕は印加電場をカットすることで素早く出力を遮断するこ とができるため安全性が高い。

（5）リハビリテーション訓練システムの可動部の慣性が大きい と, 可動部が訓練者に衝突したときの衝撃力が大きくなる ため危険である。また，勢いを利用してしまい訓練中に十 分筋力を発揮していなかったり，正しい可動域での訓練が 行えなかったりするなどの弊害も考えられる。これに対し， ER アクチュエータは慣性モーメントが小さいため, 操作 部等を含めたシステム全体の慣性を小さくすることで, 衝 突時の衝撃を最小限におさえ，かつ慣性力が訓練に与える 影響も小さくすることができる.

3.2 リハビリテーション訓練システムの開発

ERアクチュエータを用いたりハビリテーション訓練システム を開発した，開発したシステムの駆動系および訓練者を上から 見た図をFig. 5 に，またその写真を Fig. 6 に示す。このシス テムには ER アクチュエータを2台用いている。アアチチエー 夕の出力はベルトプーリシステムを用いてリンク部に伝達され る.プーリ部の減速比は 1:2.4である。平行リンク機構を用いる ことで操作部の慣性を小さくしている，第 1 リンク，第 2 リン クの長さはそれぞれ $30[\mathrm{~cm}]$ である.リンク先端にはハンドル が取り付けられている。訓練者は装置の前の椅子等に座り, コ ンピュータのディスプレイを見ながらハンドルを操作すること で仮想的な介助力あるいは抵抗力を受けながら訓練を行う。

リンクの長さがそれぞれ $30[\mathrm{~cm}]$ なので, 可動範囲はほぼ半 径 $60[\mathrm{~cm}]$ の半円内となる. ER アクチュエータの最大トルクが $4.8[\mathrm{Nm}]$ のとき, Fig. 5 の図中に示す半径約 $25 \sim 55[\mathrm{~cm}]$ の幅 


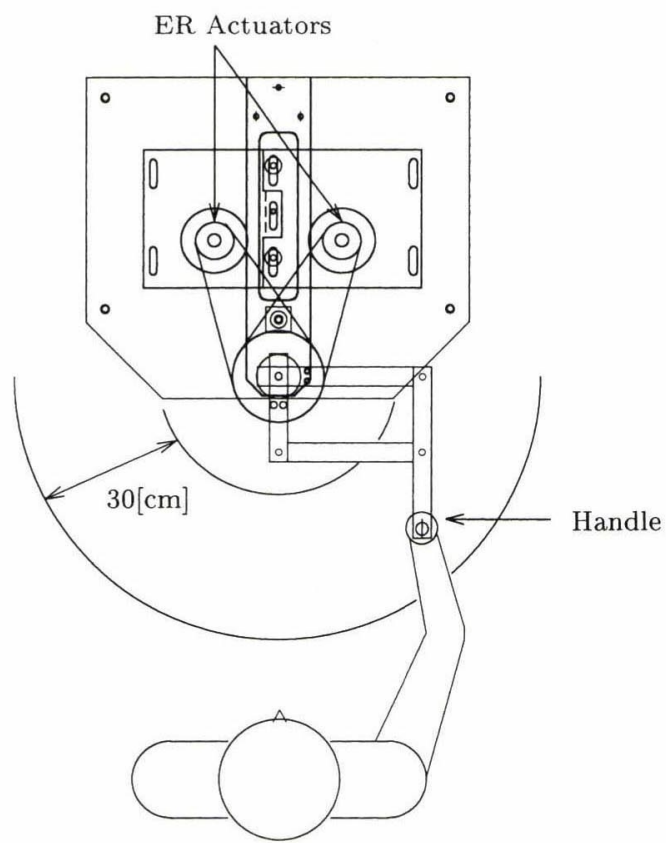

Fig. 5 Top view of mechanism of system and operator

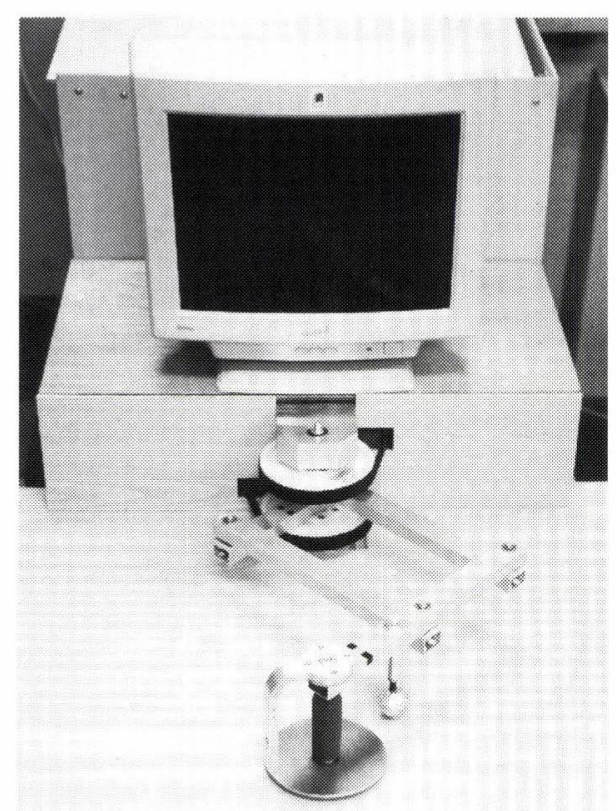

Fig. 6 Developed rehabilitation training system

$30[\mathrm{~cm}]$ の領域で，すべての方に $30[\mathrm{~N}]$ 以上，最大で約 $65[\mathrm{~N}]$ の力が提示できる。また，現在本研究で用いた ER 流体の 5 倍 程度のせん断応力を発生できる ER 流体も開発されているので, 同じ ERアクチュエータにおいて，大きなせん断応力を発生で きる ER 流体を用いれば，本システムにおいても5 倍程度大き な力を発生させることが可能である.

制御については，各アクチュエータに取り付けられた高分解 能エンコーダにより計測する角度情報からハンドルの位置, つ まり訓練者の手先の位置を計算し, 必要な補助力や抵抗力を発

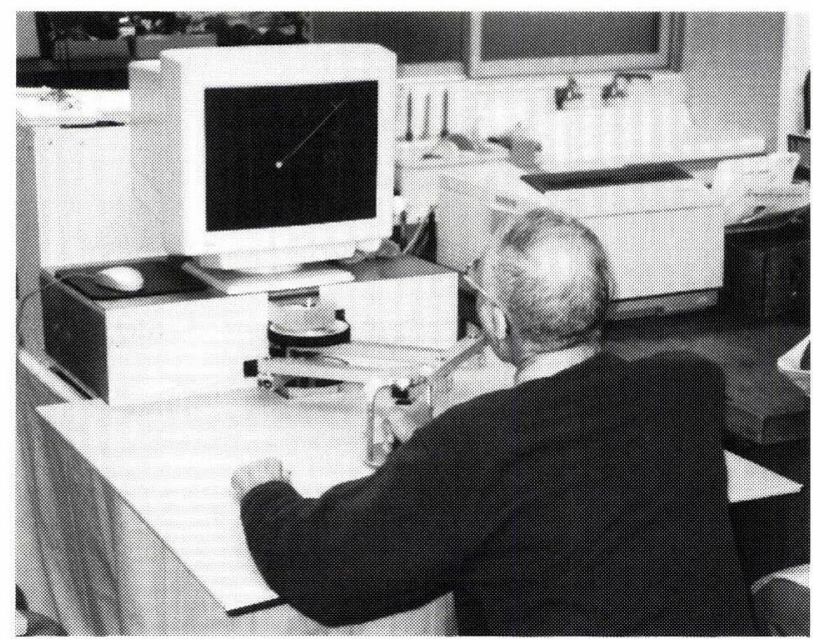

Fig. 7 Evaluation experiment at hospital

生させるためのアクチュエータのトルクを計算している. 制御 のサンプリング周期は $1.0[\mathrm{~ms}]$ である.この力覚提示システム を用いて，仮想のばねや仮想粘性場，衝突現象などの提示実験 を行ったり，比較的堅い壁として剛性が $7,500[\mathrm{~N} / \mathrm{m}]$ の壁を実 現している [15].

また，病院内において障害者の方も実験が行えるよう，イン タフェース部やシステムの外観にも配慮を行った。まず, 訓練者 の肘を乗せられるよう机を設置し, 表面には摩擦の少ないシー 卜を張り付けた。ハンドルはリンク先端の下側に取り付け，握 りやすい形に改良した。ハンドルに下向きの力が加わってもリ ンク部が破損しないように，リンク部と机の間にキャスター付 の足を取り付けた。また，周辺回路やケーブルが見えないよう カバーを取り付けた。

\section{4.リハビリテーション基礎実験}

本研究では, 開発したシステムを上肢における運動機能の巧 緻性，協調性の評価・訓練など，医学的リハビリテーション [21] に応用するためのプログラムを作成し，その効果を検証するた めの基礎実験を行った。まず大学の研究室において, 健常者の 被験者として教官および学生 20 名に対して実験を行った。次 に, 開発したシステムを病院のリハビリテーション室の中に設 置し, 主に脊髄損傷や脳血管障害により上肢に麻痺のある 13 名 の患者に対し実験を実施した。病院内での実験の様子を Fig. 7 に示す.

\section{A. 軌道追従実験}

円滑な運動を行うためには、複数の筋が調和を保って働かな ければならない。このような運動の協調性の評価と訓練を想定 し，軌道追従実験を行った，画面上に目標軌道(円，四角形，三 角形）抢よびハンドルの位置が示される。訓練者は，画面を見 ながら目標軌道に沿ってハンドルを操作する．実験の際の画面 のモデル困（円軌道の場合）を Fig. 8 に示す。ハンドルを操作 する際に, Fig. 8 に示すようにリハビリテーション訓練システ ムから訓練者に対し仮想のばねやダンパにより補助，あるいは 負荷の力を与えることができる。 


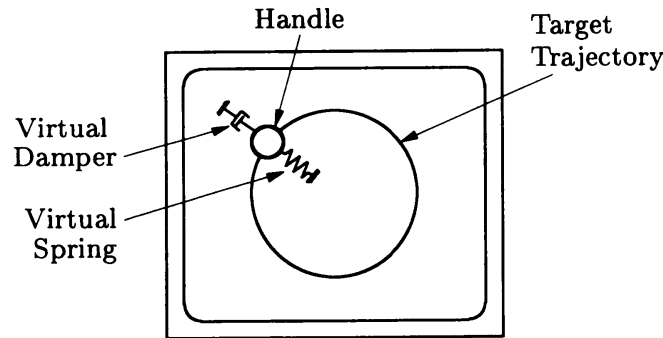

Fig. 8 Trajectory tracking experiment

Table 1 Control gains

\begin{tabular}{|l||c|c|}
\hline $\begin{array}{c}\text { Assistance } \\
\text { Condition }\end{array}$ & $\begin{array}{c}k_{p} \\
{[\mathrm{~N} / \mathrm{m}]}\end{array}$ & $\begin{array}{c}k_{d} \\
{[\mathrm{~N} \cdot \mathrm{s} / \mathrm{m}]}\end{array}$ \\
\hline \hline (a) No Assistance & 0 & 0 \\
\hline (b) by Damper & 0 & 20 \\
\hline (c) by Soft Spring & 200 & 10 \\
\hline (d) by Hard Spring & 3,000 & 50 \\
\hline
\end{tabular}

本実験では，訓練者に対し次のような力の補助を与える，八 ンドルの座標を $(x, y)$, ハンドルの位置から最も近い目標軌道 上の点の座標を $\left(X_{0}, Y_{0}\right)$ とし, 比例ゲイン行列, 微分ゲイン行 列をぞれぞれ $K_{p}, K_{d}$ とすると, ハンドル部に発生するカ $F_{x}$, $F_{y}$ は次式で与えられる。

$$
\begin{gathered}
{\left[\begin{array}{l}
F_{x} \\
F_{y}
\end{array}\right]=K_{p}\left(\left[\begin{array}{l}
X_{0} \\
Y_{0}
\end{array}\right]-\left[\begin{array}{l}
x \\
y
\end{array}\right]\right)-K_{d}\left[\begin{array}{l}
\dot{x} \\
\dot{y}
\end{array}\right]} \\
K_{p}=k_{p}\left[\begin{array}{ll}
1 & 0 \\
0 & 1
\end{array}\right] \quad, \quad K_{d}=k_{d}\left[\begin{array}{ll}
1 & 0 \\
0 & 1
\end{array}\right]
\end{gathered}
$$

仮想ばねはハンドルを目標軌道に押し戻す方向の力を発生し， 仮想ダンパはハンドルの運動速度に比例した抵抗力を発生する。 本実験では，補助および抵抗力の組み合わせとして，次の (a) (d) の四つの条件について実験を行った，各条件における制御 ゲインの值を Table 1 に示す.

(a) 補助なし（No Assistance）

(b) ダンパによる補助 (Assistance by Damper)

(c) 弱いばねによる補助 (Assistance by Soft Spring)

(d) 強いばねによる補助（Assistance by Hard Spring）

目標軌道が円の場合の患者のハンドルの軌跡を Fig. 9 に，健 常者のハンドルの軌跡を Fig. 10 に示す．患者は脳血管障害に よる左片麻瘦の 57 歳の男性, 健常者は 27 歳の男性である. 本 実験では，実験前に装置の操作についての練習は行っていない． また，ハンドルを動かす速度および方向についても特に指示を 行っていない. 実験時間はそれぞれ 30 秒間とし, 各条件の実験 を連続して行った。実験時間中にハンドルを回した回数，およ びハンドルの目標軌道からの平均誤差を Table 2 にまとめて 示す.

\section{患者の実験結果 :}

（1）条件 (a)の場合, 目標軌道からの誤差が大きく, ハンドル を回す回数が非常に少なかった。

（2）条件 (b) の場合, ハンドルの軌跡が目標軌道の内側に大き くずれた。仮想ダンパは，目標軌道とは関係なく運動の方

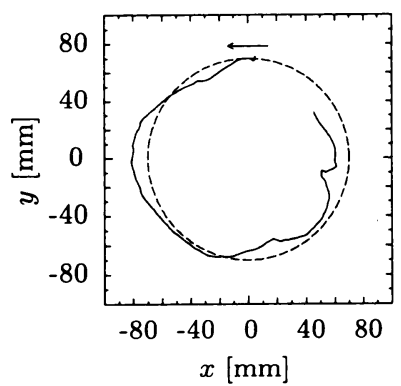

(a) No assistance

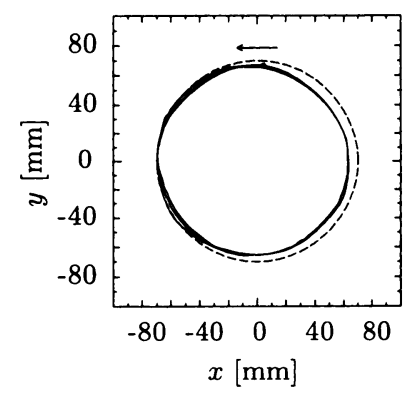

(c) Assistance by soft spring

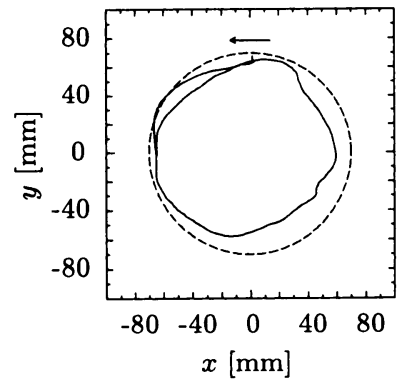

(b) Assistance by damper

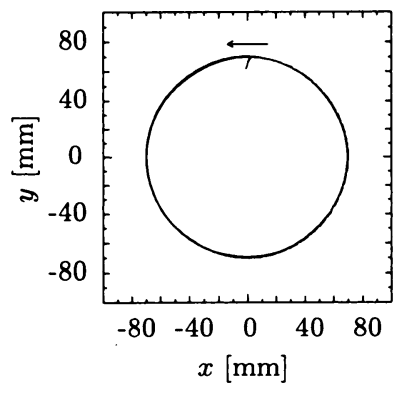

(d) Assistance by hard spring
Fig. 9 Experimental results in trajectory tracking (Patient)

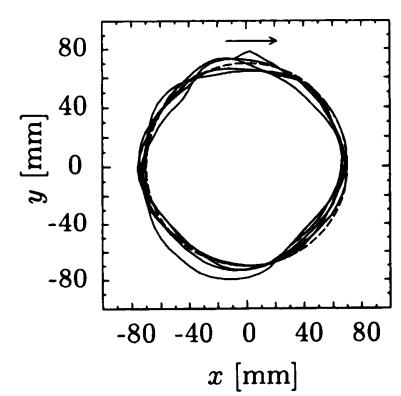

(a) No assistance

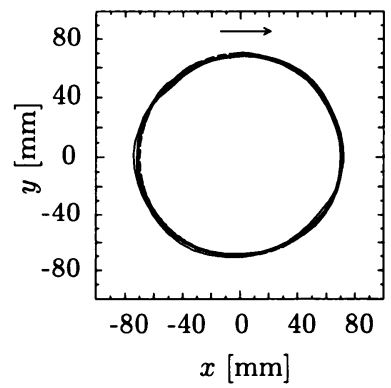

(c) Assistance by soft spring

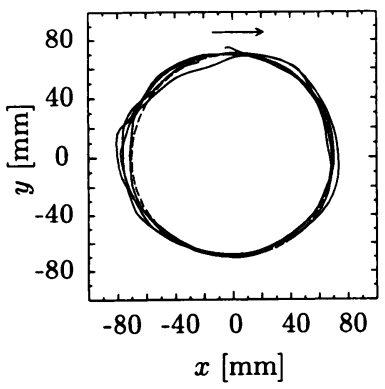

(b) Assistance by damper

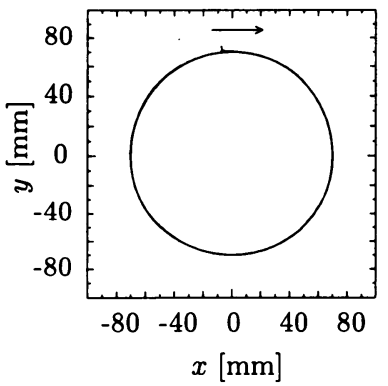

(d) Assistance by hard spring
Fig. 10 Experimental results in trajectory tracking (Normal person)

\begin{tabular}{|c|c|c|c|c|}
\hline \multirow[b]{2}{*}{$\begin{array}{l}\text { Assistance } \\
\text { Conditions }\end{array}$} & \multicolumn{2}{|c|}{ Patient } & \multicolumn{2}{|c|}{ Normal } \\
\hline & $\begin{array}{c}\text { Number } \\
\text { of Turns } \\
{[-]}\end{array}$ & $\begin{array}{c}\text { Average } \\
\text { Error } \\
{[\mathrm{mm}]}\end{array}$ & $\begin{array}{c}\text { Number } \\
\text { of Turns } \\
{[-]}\end{array}$ & $\begin{array}{c}\text { Average } \\
\text { Error } \\
{[\mathrm{mm}]}\end{array}$ \\
\hline (a) No Assistance & 0.7 & 6.7 & 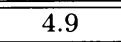 & 3.2 \\
\hline (b) by Damper & 1.3 & 9.0 & 2.9 & 2.5 \\
\hline (c) by Soft Spring & 2.5 & 3.4 & 6.0 & 1.3 \\
\hline (d) by Hard Spring & 2.5 & 0.3 & 5.0 & 0.1 \\
\hline
\end{tabular}

Table 2 Laps and errors (Experimental results) 
向と逆の方向に抵抗力を発生するため, 患者が思った通り の運動ができず，軌跡が内側にずれたと考えられる。

（3）条件 (c)の場合, 条件 (a) および条件 (b) と比べて目標軌 道からのずれが大幅に減少した，これは，仮想ばねの力が ハンドルを目標軌道に近づける方向に㗢き，補助として作 用したためであると考えられる。また，ハンドルを回す回 数も増加した。これは, 仮想ばねの効果で目標軌道からの ずれが減少したため，ハンドルを目標軌道に近づける動作 があまり必要なくなり，その分ハンドルを回す動作が多く なったと考えられる。

（4）条件 (d)の場合，(c)のときとハンドルを回す回数は変わ らなかったが，誤差が非常に小さくなった。これは，仮想 ばねの補助が強かったため，小さなずれが発生しても，患 者の操作力と比べて大きな補助力が発生したためであると 考えられる。

健常者の実験結果 :

（1）条件 (a)の場合，ハンドルを回す回数が多かった。これは, 抵抗力がなかったため, 速い速度で自由にハンドルを操作 できたためであると考えられる。しかし，目標軌道からの ずれも，他の条件と比べて大きかった。これは，腕の慣性 が支配的となったためであると考えられる。

（2）条件 (b) の場合，条件 (a) と比べてハンドルを回す回数が 減少した。これは，仮想ダンパのためハンドルの運動速度 に比例した抵抗力が発生し，運動速度が遅くなったことが 原因である。また，誤差もわずかに減少した。これは，運 動速度が遅くなったこと，および仮想ダンパによる安定化 効果のためと考えられる。この誤差の減少は, 患者の実験 結果では見られなかった。

（3）条件 (c)の場合，同じ条件の患者の実験結果と同様に, 目 標軌道からのずれが大幅に減少した。また，ハンドルを回 す回数は，条件 (a)の補助がない場合と比べて増加した。

（4）条件 (d)の場合，目標軌道からの䛊差はほとんど発生しな かった。 ハンドルを軽く握って仮想ばねの力に倣うことで， 正確な円軌道を描くことができた。

軌道追従実験の結果については, 全体的に次のような傾向が 見られた．まず，仮想ばねによる補助は，患者および健常者のど ちらにとっても効果的で，ばね定数を大きくすることで䛊差は 減少した，仮想ダンパの抵抗力は，患者にとっては負担となる ことがあったが, 健常者の場合補助なしの場合と比べて安定性 が増し，誤差を小さくするためには有効であったと考えられる．

本実験は，まず第 1 段階として 13 名の患者，および 20 名の 健常者に対し基礎実験を行った。この結果から，システムから の補助力の変化によってハンドルの軌跡に有意な変化が見られ るため, 患者の状態にあわせて制御ゲインを設定し, 回復の度 合いにあわせたゲイン設定を行うことで，有効なリハビリテー ション訓練，および評価を行うことが可能であると考えられる．

\section{B. 目標追跡実験}

運動パターンの獲得等を想定し，2 種類の目標追跡実験を行つ た、ロボットにおける PTP (Point-to-Point) 制御に相当する.

Fig. 11 に，2点追跡実験における画面のモデル図を示す。目標 点は，画面上の 2 箇所を一定時間ごとに左右に移動する，訓練

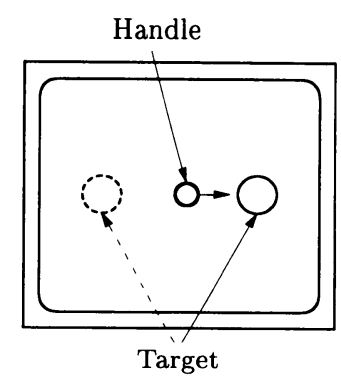

Fig. 11 Two target following experiment

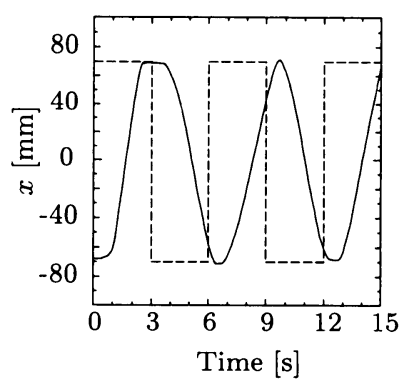

(a) Patient

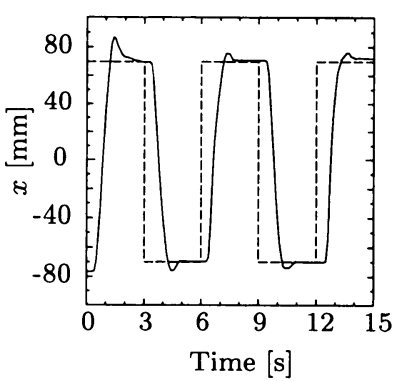

(b) Normal person
Fig. 12 Experimental results in two target following

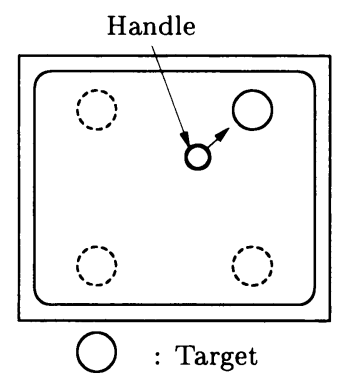

Fig. 13 Four target following experiment

者は，画面を見ながらハンドルを操作して目標を追跡する，目 標に至るまでの軌道については特に指示していない.このとき システムから様々な負荷抵抗を与えることができる.

粘性抵抗（粘性係数: $20[\mathrm{~N} \cdot \mathrm{s} / \mathrm{m}]$ ) を与えながら実験を行った 際の実験結果をFig. 12 に示す。図の横軸は時間, 縦軸は目標 またはハンドルの左右方向の移動距離を表す. 図中の破線は目 標の動きに，実線はハンドルの動きに対応する。Fig.12(a)は 患者による実験結果である．動きが遅く，3秒間では目標まで 達していないことが分かる. Fig. 12 (b) は健常者の実験結果で ある. 患者と比べて動作が速く, 約 1 秒で目標に達し, 数セン チほど行き過ぎを生じている。

Fig. 13 は，4点追跡実験における画面のモデル図を示す。 2 点追跡実験では目標は一定時間ごとに移動したが，4点追跡 実験ではハンドルが目標に追いつくとすぐに残りの 3 箇所の いずれかの場所に目標が移動する．実験時間内にできるだけ多 くの目標を追跡するよう指示を行った。粘性抵抗（粘性係数： $20[\mathrm{~N} \cdot \mathrm{s} / \mathrm{m}])$ を与えながら実験を行った際の実験結果を Fig. 14 に示す. Fig. 14 (a)の患者の場合, 30 秒間で 14 回しか目標に 


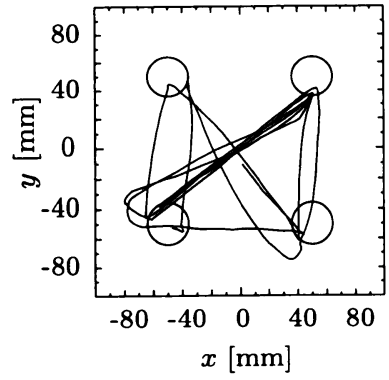

(a) Patient

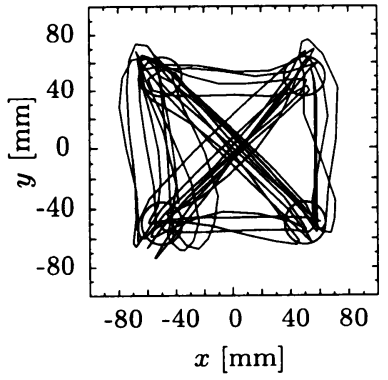

(b) Normal person
Fig. 14 Experimental results in four target following

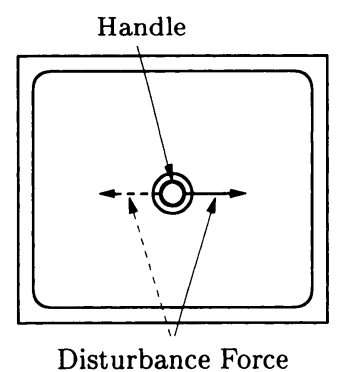

Fig. 15 Force control experiment

到達できなかったが, Fig. 14 (b) の健常者の場合は 39 回到達 できた。

また，Fig. 14 とは別の実験において，ハンドルを動かしにく い方向がある患者の場合，その影響がハンドルの軌跡に見られ たケースがあった。

\section{C. 位置保持実験}

筋力の応答性や制御性の評価および訓練を想定し，外乱力に 対する位置保持実験を行った. Fig. 15 に画面のモデル図を示 す．訓練者は，ハンドルを画面の中央に対応する場所に保持す る. 実験中は，ステップ状の外乱力が一定時間ごとにハンドル に与えられる. 外乱力が与えられた瞬間や外乱力がゼロとなっ た瞬間にハンドルの位置がずれるので, 素早く元の位置に戻す よう指示を行った。

Fig. 16 に実験結果を示す。横軸は時間, 縦軸左はハンドルの 移動距離, 縦軸右は外乱力の大きさを表す。図中の実線はハン ドルの位置，破線は外乱力の変化の様子に対応する．Fig. 16 (a) に，患者による実験結果を示す．3〜6秒において $-14[\mathrm{~N}]$ の外 乱力が加わった場合, ハンドルの位置は約 $-60[\mathrm{~mm}]$ 動いた後 $-20[\mathrm{~mm}]$ 付近で止まり，指定位置まで戻すことができていな い.また，9〜12 秒において，14[N] の外乱力が加わった場合， ハンドルのずれは $20[\mathrm{~mm}]$ 程度であるが, 指定位置に戻るまで 約 2 秒時間がかかっている。このように，十分に力の制御がで きていないことが分かる。これは片麻㾇による固縮や㾏性の影 響と考えられる。これに対し，Fig. 16 (b) に健常者による実験 結果を示す. $3 \sim 6$ 秒および 9 12 秒において，28[N] の大き さの外乱力が加わっている.このとき，ハンドルのずれは 40〜 $80[\mathrm{~mm}]$ 程度で, 患者の結果に比べて大きい。しかし，1 秒程 度でハンドルを指定位置まで戻し，外乱力と釣り合いを保って

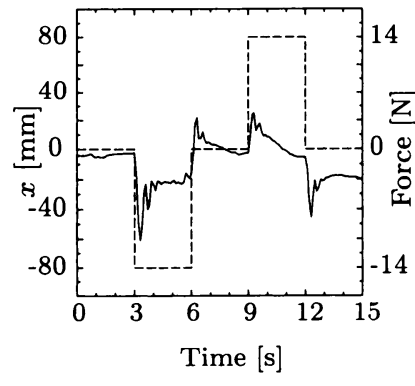

(a) Patient

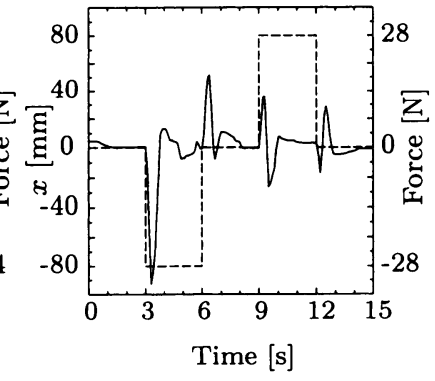

(b) Normal person
Fig. 16 Experiment results in froce control

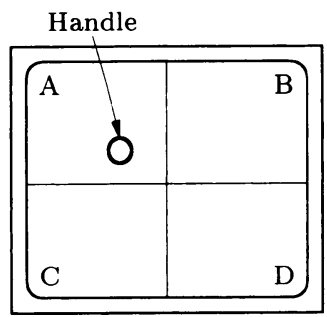

Fig. 17 Kinesthesia experiment

いることが分かる.

\section{D. 運動感覚実験}

筋感覚, 運動感覚の評価と訓練を想定し, 運動感覚実験を行っ た．Fig. 17 に画面のモデル図を示す．画面上の四つに仕切ら れた $\mathrm{A} \sim \mathrm{D}$ の領域はそれぞれ異なる粘性係数が設定してあり， 訓練者はハンドルを自由に動かすことで，その抵抗力を知覚す る. 粘性係数をそれぞれ $0,5,10,15[\mathrm{~N} \cdot \mathrm{s} / \mathrm{m}]$ と設定した。こ の実験は健常者のみに対して行ったが，ほほ全員が容易に粘性 倸数を識別することが可能であった。

\section{5.おわりに}

本研究では，ER アクチュエータを用いたリハビリテーショ ン訓練システムの開発について検討し，以下の結論を得た。

（1）力発生部に ER 流体を用いた ERアクチュエー夕を開発し, 人間と共存しながら働く機械システムに ER アクチュエー 夕を応用する際の利点について検討したＥRアクチュエー 夕は, 既存のサーボモータと比べて制御性, 安全性の面で 力覚提示システムやリハビリテーション訓練システム等に 適した特性を持つ。

（2）ERアクチュエー夕を用いたリハビリテーション訓練システ ムを開発した。開発したシステムは, 病院のリハビリテー ション訓練室において障害者の方も実験を行えるように，八 ンドル等のインタフェース部を改良したり，テーブル部を 構成したりするなど配慮を行った。その結果，障害者でも ハンドルを把持し，时をテーブルの上に置きながら実験を 行うことができた。

(3）開発したリハビリテーション訓練システムの有効性を検証 するため，上肢に扔ける運動機能，特に巧緻性や協調性の 評価および訓練を想定した基碟実験プログラムを開発した。 
（4）開発したシステムの有効性を検証するために基礎実験を行っ た. 大学の研究室における健常者に対する実験だけでなく, 開発したシステムを病院のリハビリテーション訓練室の中 に設置し，上肢に麻痺のある患者に対して基礎実験を行っ た。実験結果から，訓練者の能力に合わせて制御パラメー 夕を適切に変化させることで, 有効なリハビリテーション 訓練および評価が行える可能性を確認した。

今後, 十分な臨床試験を行うことにより，開発したシステム による訓練効果を定量的に評価することが必要である。最後に， 本研究において実験にご協力頂いた中部労災病院の患者ならび にスタッフの方々に謝意を表します.

\section{参 考 文 献}

[1] 土肥：“高龄社会における医療福祉工学”, BME, vol.13, no.8, pp.3338, 1999.

[2] 藤江：“超高齢・少子化社会生活に支援してくれるロボット・メカト 口機器”, 日本機械学会誌, vol.100, no.944, pp.750-754, 1997.

[ 3 ] 土居：“機能回復訓練装置”, バイオメカニズム学会誌, vol.17, no.2, pp.99-105, 1993.

[4] H.I. Krebs, N. Hogan, M.L. Aisen, and B.T. Volpe: "RobotAided Neurorehabilitation," IEEE Trans. on Rehabilitation Engineering, vol.6, no.1, pp.75-87, 1998.

[5] T. Noritsugu and T. Tanaka: "Application of Rubber Artificial Muscle Manipulator as a Rehabilitation Robot," IEEE/ASME Trans. on Mechatronics, vol.2, no.4, pp.259-267, 1997.

[6] 本間, 新井: “パラレルメカニズムを用いた上肢動作補助機構”, 日本 ロボット学会誌, vol.15, no.1, pp.90-96, 1997.

[7] 岡島, 内田, 榊, 富田, 千野: “下肢可動域訓練ロボットの開発一柔 らかさと剛さを兼ね備えたストレッチ装置—”, 医用電子と生体工学, vol.37, no.3, pp.293-300, 1999.

$\{8]$ 谷, 酒井, 小関, 服部, 藤江：“能動インピーダンス制御を用いた訓
練用歩行路面の検討”, 日本機械学会論文集 ( C 編), vol.63, no.613, pp.3168-3173, 1996.

[9] 大森, 山田, 網本：“新しいコンセプトの運動負荷装置”, 理学療法 ジャーナル, vol.33, no.6, pp.387-393, 1999.

[10] 宮本：“高齢化社会支援機器に要求されるセンサ・アクチュエータ技 術”, 日本ロボット学会誌, vol.11, no.5, pp.628-632, 1993.

[11] Y. Wakisaka, M. Muro, T. Kabutomori, H. Takeda, S. Shimizu, S. Ino, and T. Ifukube: "Application of Hydrogen Absorbing Alloys to Medical and Rehabilitation Equipment," IEEE Trans. on Rehabilitation Engineering, vol.5, no.2, pp.148-157, 1997.

[12] 柄川, 藤江, 樋口：“介護機器用静電アクチュエー夕の基礎検討”，日 本ロボット学会誌, vol.15, no.8, pp.1147-1155, 1997.

[13] 坂口, 古荘, 章, 魏：“ER アクチユエータの開発およびその力制御に関 する基䃈研究”, 日本ロボット学会誌, vol.16, no.8, pp.1108-1114, 1998.

[14] 坂口, 章, 古荘：“ER アクチユエータのモデリングと運動制御”，日 本機械学会第 76 期全国大会講演論文集 (IV), pp.202-203, 1998.

[15] 坂口, 古荘: “ERアクチュエータを用いた 2 次元力覚提示システムの開 発”, 日本バーチャルリアリテイ学会論文誌, vol.3, no.3, pp.133-140, 1998.

[16] W.M. Winslow: "Induced Fibration of Suspensions," J. of Applied Physics, vol.20, pp.1137-1140, 1949

[17] 小山監修：電気粘性（ER）流体の開発. シーエムシー, 1999.

[18] 古荘： "ER 流体を用いたメカトロニクス機器の制御”, 計測と制御, vol.34, no.9, pp.687-691, 1995.

[19] W.A. Bullough et al.: "ER Shear Characteristics: Volume Fraction, Shear Rate, Time Response," Trans. of ASME, J. of Dynamic Systems, Measurement, and Control, vol.118, pp.221$225,1996$.

[20] 坂口, 音羽, 加藤, 古荘: “ER 流体を用いた小型高性能アクチュエー 夕の開発に関する基礎研究”, 日本機械学会ロボティクス・メカトロ ニクス講演会'99 講演論文集, 2P1-48-077, 1999.

[21] 上田：目でみるリハビリテーション医学第 2 版. 東京大学出版会, 1994.

[22] 大井, 博田編修：運動療法第 2 版. 医菌薬出版, 1982 .

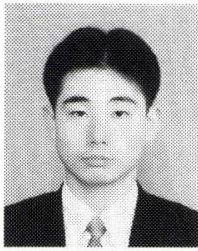

坂口正道 (Masamichi Sakaguchi)

1970 年 6 月 29 日生. 1995 年 3 月電気通信大学 大学院電気通信学研究科機械制御工学専攻博士前 期課程修了, 1995 年 10 月同大学大学院博士後期 課程退学. 1995 年日本学術振興会特別研究員. 電 気通信大学助手を経て，1996 年 4 月より大阪大学 助手, 現在同大学大学院工学研究科電子制御機械 工学専攻助手. 機能性流体老用いたメカトロニクス機器の開発およ びその応用に関する研究に従事. 日本機械学会, 日本バーチャルリ アリテイ学会, バイオメカニズム学会, 計測自動制御学会などの会 員.

(日本ロボット学会正会員)

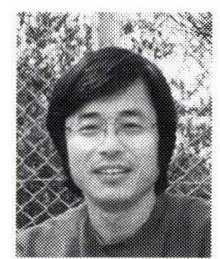

元田英一 (Eiichi Genda)

1948 年 10 月 29 日生. 1974 年名古屋大学工学 部機械工学科卒業. 1981 年名古屋大学医学部医 学科卒業. 医学博士. 1994 1996 年 Johns Hopkins University Biomechanics Lab. に留学. 1997 年より労災リハビリテーション工学センター勤 務。筋骨格システムのコンピュータシミュレーシ ヨン, 整形外科手術のコンピュータシミュレーション, 麻痺患者 の運動機能再建の研究に従事. 日本臨床バイオメカニクス学会, 日本整形外科学会, 日本リハビリテーション医学会などの会員.

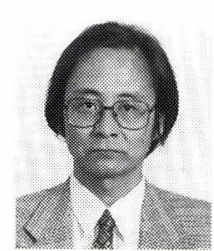

古荘純次 (Junji Furusho)

1947 年 3 月 22 日生. 1970 年大阪大学工学部機械 工学科卒業, 1975 年同大学大学院博士課程単位取 得退学. 大阪大学助手, 岐皋大学助教授, 電気通信 大学教授を経て 1996 年より大阪大学工学部教授. 工学博士．ロボット・メカトロニクス機器の制御お よび機能性流体のヒューマンインタフェースへの応 用に関する研究に従事. 日本機械学会, 計測自動制御学会, システム 制御情報学会, 電気学会, 日本バーチャルリアリテイ学会, バイオメ カニズム学会などの会員.

(日本ロボット学会正会員) 